\title{
The Prospect of Utilizing a Cassava Derivative $(F u f u)$ as a Fluid Loss Agent in Water Based Drilling Muds
}

\author{
Samavati R., Abdullah N., Tahmasbi Nowtarki K., Hussain S. A., and Awang Biak D. R.
}

\begin{abstract}
This work presents an investigation on a Nigerian local cassava derivative $(f u f u)$ as a fluid loss agent in water-based drilling mud formulation. The rheological and fluid loss behavior was compared with commercial fluid loss agents (potato and corn starch) in actual drilling condition. The study was conducted at temperatures of $250^{\circ} \mathrm{F}-300^{\circ} \mathrm{F}$. The mud weights used were 75,100 and 150 pcf. The results from characterization analysis revealed that $f u f u$ contained higher protein content as compared to other starch. Fufu exhibited an acceptable fluid loss (under $2 \mathrm{ml}$ ) at $250^{\circ} \mathrm{F}$ in all mud weights formulations, while potato and corn-based mud failed at light-weight formulation. Most of the starches formulation failed and completely degraded when the temperature was set at $300^{\circ} \mathrm{F}$. This study showed a potential of fufu starch to be used as a fluid loss agent in drilling mud.
\end{abstract}

Index Terms-Drilling mud, fluid loss, fufu, starch.

\section{INTRODUCTION}

A successful drilling procedure depends on the appropriate mixture and supervision of the drilling fluid/mud. By taking the technological economics and ecological factors into consideration, good drilling depends on the functionality of the drilling fluids system, because during drilling process the mud would gain further viscosity which leads to speed rate reduction of the drilling bits [1]. Drilling fluid compositions relies very much on the requirements of the individual drilling procedure [2], [3].

Various types of chemicals and polymers are applied in petroleum manufacturing for various drilling fluids formulations to convene different practical mud requirements such as density, rheology and fluid loss control etc. [4]. One of the drilling mud additives is starch/polymers for fluid loss control. Starch next to cellulose is the most abundant substance in nature and is made of two sections; amylose and amylopectin [5]. Amylose section is responsible for the gelling function, while amylopectin reduces polymers movements and profusion in hydroxyl assemblies within the starch molecules and expressing hydrophilic property of the polymers and therefore makes it possible to dissolve in water.

Starch is typically applied in drilling fluids technology by customized forms because of its solubility in water. They are principally applied to diminish the filtration of virtually all types of water based drilling fluids, owing to their swelling ability. This swelling assortment diminishes muds permeability, decreases the mud filterability and hence causing fluid loss on borehole areas. There is an opportunity

Manuscript received October 9, 2013; revised November 30, 2013.

The authors are with the Faculty of Chemical and Environmental Engineering, Universiti Putra Malaysia, 43400, UPM Serdang, Malaysia (e-mail: Samavati_Raheleh@yahoo.com,nhafizah@upm.edu.my). of filtration management by appropriate consumption of starch ingredients and their combination with polymers and bentonite [6], [7]. Among the most commonly used filtration control agents reported are biopolymers, synthetic polymers and sodium bentonite [8].

A fluid loss phenomena is occurred when a superior hydrostatic force applies to mud formation. The leakage of fluid may present multiple drilling tribulations such as structure destruction and stuck pipe. Therefore, by applying a fluid loss control agent (also known as filtrate reducing additives), tendency of drilling mud fluid loss will be diminished [9]-[11]. A study by Chin [12] revealed that incorporating particles into the mud system has a significant role in preventing fluid loss.

At present, polyanioniccellulose (PAC), a cellulose based fluid loss agent is one of the commonly used fluid loss control agents in drilling mud industry. In view of the fact that the importation of PAC is costly, there is a necessity for less expensive polymers, preferably local resources like corn, potato starch as an alternative to the PAC [13]-[15]. PAC has showed a better function in water based mud when it's combined with a sulfonatic polymer and aged in the temperature of $300^{\circ} \mathrm{F}$ [16].

A number of corn-based starches were developed as drilling fluid additive by Amanullah and Long. Their results showed a good filtration control property by some of the corn-based formulation, comparable to the commercial starch [17]. A study by Okumo and Isehunwa in 2007 presented a basic rheological investigation of potash and cassava starch water based drilling muds (WBM) in different temperatures. Viscosity evaluations obtained were compared to the experimental results and showed that the formation has $93.6 \%$ accuracy [18]. There has been little investigation on basic assets and functional properties of various cassava starches for managing the viscosity and fluid loss in WBMs [19], [20]. These studies were done based on laboratory environment and not within the actual industrial drilling condition. Therefore, further investigation on the influence of functional properties of various cassava starches on drilling fluid loss and viscosity parameters under different bore well conditions and temperatures, which are acceptable by the industrial standards and not just laboratorial investigations, is needed.

Drilling mud applied for off-shore and on-shore drilling is often similar in formulation, depending on well condition [21], [22]. For on-shore drilling, the depth of the well could reach $7500 \mathrm{~m}$ [23]. As described by Oil Industry Network of Iran [24], the average drilling depth in Iran is between $3500 \mathrm{~m}$ to $4500 \mathrm{~m}$ and the temperature is between $200^{\circ} \mathrm{F}$ to $275^{\circ} \mathrm{F}$. Generally in Iran, different mud weights (pcf) are applied depending on the wells hole size, which are:

1) $12 \frac{1}{4} \mathrm{~m}$ Hole Section: $150 \mathrm{pcf}$ of mud weight (heavy mud) 
2) $81 / 2$ m Hole Section: 75 and 100 pcf of mud weight (light to average mud)

3) 6m Hole Section: 75 and 100 pcf of mud weight (light to average mud)

\section{Cassava and Cassava Derivative Products}

The development and utilization of cassava has implicated significant role in numerous regions of West Africa, principally as mankind food and as a nourishing material for farm animals. Cassava is an inexpensive supply of carbohydrate and one of the main rations in Nigeria. In Nigeria, cassava tubers are locally developed into garri, fufu and cassava flour (lafun) as well as cassava starch [25]-[27]. Fufu is product of skinned cassava that was drenched and permitted to be fermented for around five days. After the fermentation, cassava is crushed, sieved and left to settle. The resulted paste is recognized as Fufu[28]. The paste then was weakened by water and left on a mild heat with steady stirring to ferment. Fufu involves no additional procession before beeing cooked to a thick jelly formation for consumption [25], [ 29], [30].

\section{Methodology}

\section{A. Materials}

In this study, the cassava derivative Fufu was purchased from Chow Kit market in Kuala Lampur, Malaysia and applied as fluid loss agent. As a comparison, potato and corn-starches were used as a benchmark for fluid control product. They were bought from shops in Tehran, Iran. Saturated salt water was consumed as the fundamental material for the mud formulation prepared in the Pars Drilling Fluid Company laboratory (Tehran, Iran). Barite $\left(\mathrm{BaSO}_{4}\right)$ and hematite $\left(\mathrm{Fe}_{2} \mathrm{O}_{3}\right)$ were functioned as viscofiers, sodium hydroxide $(\mathrm{NaOH})$ for $\mathrm{pH}$ elevation and corrosion resistant, sodium chloride $(\mathrm{NaCl})$ as mud swelling controller, density enhancer and also to perform as a bridge in saturated solutions. These additives were purchased from Iran Kaolin and Barite Company (IKB Co.) in Tehran, Iran.

\section{B. Production of Drilling Mud}

Investigation on the suitability of $F u f u$ as a fluid loss control in light, average and heavy mud weights formulation was performed according to the American Petroleum Institute (API) and National Iranian South Oil Company (NISOC) standards for water based drilling mud.

The experiment was conducted in Drilling Mud Laboratory at Pars Drilling Company (Tehran, Iran). Mud samples $(75,100$ and 150 pcf of mud weight) were prepared according to Table I. Briefly, $350 \mathrm{cc}$ of saturated water, $14 \mathrm{~g}$ of Fufu (or other fluid loss agent) and appropriate amount of barite and hematite were mixed together. The weight of barite and hematite added was varied based on intended proportion and desired mud weight, according to equation (1)-(3) below:

$$
\begin{gathered}
V_{\mathrm{s}}+V_{\mathrm{m} 1}=V_{\mathrm{m} 2} \\
\rho_{\mathrm{s}} V_{\mathrm{s}}+\rho_{\mathrm{m} 1} V_{\mathrm{m} 1}=\rho_{\mathrm{m} 2} V_{\mathrm{m} 2} \\
\rho_{\mathrm{s}} V_{\mathrm{s}=} \rho_{\mathrm{s}} V_{\mathrm{m} 2}\left(\rho_{\mathrm{m} 2}-\rho_{\mathrm{m} 1}\right) / \rho_{\mathrm{s}}-\rho_{\mathrm{m} 1}
\end{gathered}
$$

where
$V_{\mathrm{s}}=$ volume of solid, $V_{\mathrm{m} 1}=$ volume of initial mud, $V_{\mathrm{m} 2}=$ final volume of mixture, $\rho_{\mathrm{s}}=$ density of solid, $\rho_{\mathrm{m} 1}=$ density of initial mud, $\rho_{\mathrm{m} 2}=$ density of final mud

TABLE I: THE COMPOSITION OF THREE Mud SAMPLES IN DIFFERENT MUD WeIGHTS (Mud WEIGHTS WERE SET ACCORDING TO DRILLING WELL PRESSURE/APPLICATION AND NISOC STANDARDS FOR DRILLING MUDS)

\begin{tabular}{|l|c|c|c|}
\hline \multicolumn{1}{|c|}{ Mud Composition } & Sample \#1 & Sample \#2 & Sample \#3 \\
\hline $\begin{array}{l}\text { Saturated Salt Water } \\
\text { (Mud base) }\end{array}$ & $350 \mathrm{cc}$ & $350 \mathrm{cc}$ & $350 \mathrm{cc}$ \\
\hline $\begin{array}{l}\text { Starch/Fluid Loss } \\
\text { Agent }\end{array}$ & $14 \mathrm{~g}$ & $14 \mathrm{~g}$ & $14 \mathrm{~g}$ \\
\hline Barite (Viscofier) & - & $226 \mathrm{~g}$ & $900 \mathrm{~g}$ \\
\hline Hematite (Viscofier) & - & - & $70 \mathrm{~g}$ \\
\hline Mud Weight & $75 \mathrm{pcf}$ & $100 \mathrm{pcf}$ & $150 \mathrm{pcf}$ \\
\hline
\end{tabular}

After ensuring the accurate weight, mud samples were poured to mixing cup and placed in the multi-mixer for mixing until homogenous. Then $\mathrm{pH}$ was measured using $\mathrm{pH}$ meter (model ION510, USA). For the mud samples with a pH below 8.5, an addition of sodium hydroxide was essential for $\mathrm{pH}$ adjustment to the degree of 8.5-9.5 which is the most preferred $\mathrm{pH}$ for drilling fluids at which starch presents better efficiency.

Mud samples were then placed in a rolling oven manufactured by Fann (model 705ES, USA), preset at a desired temperatures for 8 hours. The rolling oven works by heating the samples as under constant circulation, to simulate the drilling well resembling the same conditions mud be experiencing in the actual drilling operation. After 8 hours of constant heating and circulation, aging cells were ejected with caution since they were really hot and left aside to cool for 30 minutes. After cooled to room temperature, the muds were ready for rheology and fluid loss analysis.

\section{Rheological Analysis}

Mud rheological characterization were carried out by viscometer manufactured by OFITE (model 800, USA) in six different speeds $(600,300,200,100,6$ and $3 \mathrm{rpm})$. This analysis provided rheological data such as amount of apparent viscosity (AP), plastic viscosity (PV), yield point (YP), gel strength (GS) and $\mathrm{pH}$. These rheological properties are defined as follows:

$$
\begin{aligned}
& \mathrm{PV}: \mu_{p}=\phi_{600}-\phi_{300} \\
& \mathrm{AV}: \mu_{a F}=1 / 2 \phi_{600} \\
& \mathrm{YP}: Y_{b}=\phi_{300}-\mu_{p}
\end{aligned}
$$

where

$\phi=$ Torque readings from instrument dial at 600 and 300 round per minute (rpm).

\section{Determination of Fluid Loss}

Investigation on the fluid loss properties was carried out using an API proved high pressure-high temperature filter press (HPHT) manufactured by Fann (model 3878, USA). The HPHT fluid loss examination, investigates drilling fluid filtration into formation within a static state in excess of assured period of time capable to vary the pressure and temperature to simulate the probable down-hole situations. The experiment was performed under 500 psi differential pressure for 30 minutes. 


\section{RESUlTS AND DisCUSSION}

Assessment on applicability of fufu as fluid loss agent in drilling mud based on API and NISOC standard requirements were investigated. The results on PV, YP, AV, GS and fluid loss obtained when the fufu mud subjected to temperatures of $250^{\circ} \mathrm{F}$ to $300^{\circ} \mathrm{F}$, emulating drilling well conditions and compared with commercial fluid loss starches (corn and potato).

All the subsequent experiments were carried out in three different mud weights $(75,100$ and 150 pcf $)$, which represent the mud weight applied for by NISOC standards in exact industrial formulations of onshore circumstances.

\section{A. Starch Characterization Analysis}

Prior to rheological and fluid loss studies, an assessment on compositional content was performed.

TABLE II: THE CHARACTERIZATION ANALYSIS OF FUFU COMPARED TO

\begin{tabular}{|c|c|c|c|c|}
\hline \multicolumn{1}{c|}{ CORN AND POTATO STARCH } \\
\hline $\begin{array}{c}\text { Technique } \\
\text { Applied }\end{array}$ & $\begin{array}{c}\text { Samples } \\
\text { Properties }\end{array}$ & Fufu & Potato & Corn \\
\hline $\begin{array}{c}\text { Oven-Direct } \\
\text { Heat }\end{array}$ & $\begin{array}{c}\text { Humidity } \\
(\%)\end{array}$ & 12.73 & 11.22 & 10.22 \\
\hline pH meter & $\mathrm{PH}$ & 5.43 & 4.8 & 5.8 \\
\hline $\begin{array}{c}\text { Digestion\& } \\
\text { Distillation System }\end{array}$ & $\begin{array}{c}\text { Protein } \\
(\%)\end{array}$ & 3.85 & 0.8 & 0.66 \\
\hline Soxhlet Method & Fat (\%) & 0.4 & 0.68 & 8 \\
\hline Muffle Furnace & Ash (\%) & 0.4 & 2.1 & 0.16 \\
\hline
\end{tabular}

A cassava derivative $f u f u$, potato and corn-starch, were evaluated for their characterization using proximate analysis. Table II presents overall properties for all the starches. Fufu exhibited a significant different in protein content with the highest amount at $3.85 \%$, as compared to corn and potato (0.66 and $0.8 \%$, respectively).

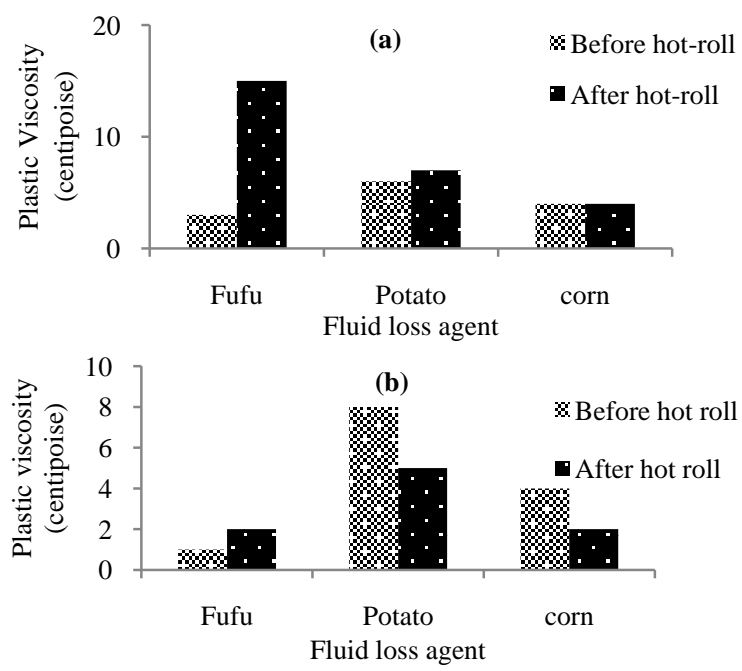

Fig. 1(a). The plastic viscosity before and after hot-roll in $250^{\circ} \mathrm{F}$ in mud weights of $75 \mathrm{pcf}$ (b) The plastic viscosity before and after hot-roll in $300^{\circ} \mathrm{F}$ in mud weights of 75 pcf.

\section{B. The effect of Hot-Roll Temperature on Plastic Viscosity}

Two sets of temperature $\left(250\right.$ and $\left.300^{\circ} \mathrm{F}\right)$ were assessed for each mud weight $(75,100$ and $150 \mathrm{pcf})$. Fig. 1(a) presents the plastic viscosity of fufu raised significantly after subjected to hot-roll at $250^{\circ} \mathrm{F}$ with mud weight of $75 \mathrm{pcf}$, as compared to potato and corn which retained approximately the same PV value. PV has direct relation on the limit and number of available solid particles. In other words, when the PV values of mud increased, it shows increasing amount of inactive solid materials in the mud.

An opposite reaction has occurred when the hot roll was set at $300^{\circ} \mathrm{F}$, from which the PV value of potato and corn starch been reduced, significantly while $f u f u$ had a slight increase to its PV, as shown in Fig. 1(b).

When the mud formulation was increased to average (100 pcf) and heavy (150 pcf) weight, a similar PV pattern that observed in light mud weight (75 pcf) was obtained. This was observed in both hot-roll temperatures of $250^{\circ} \mathrm{F}$ and $300^{\circ} \mathrm{F}$ (Fig. 2 and Fig. 3). The quantitative PV values were higher in heavy mud compared to average and light mud formulation.
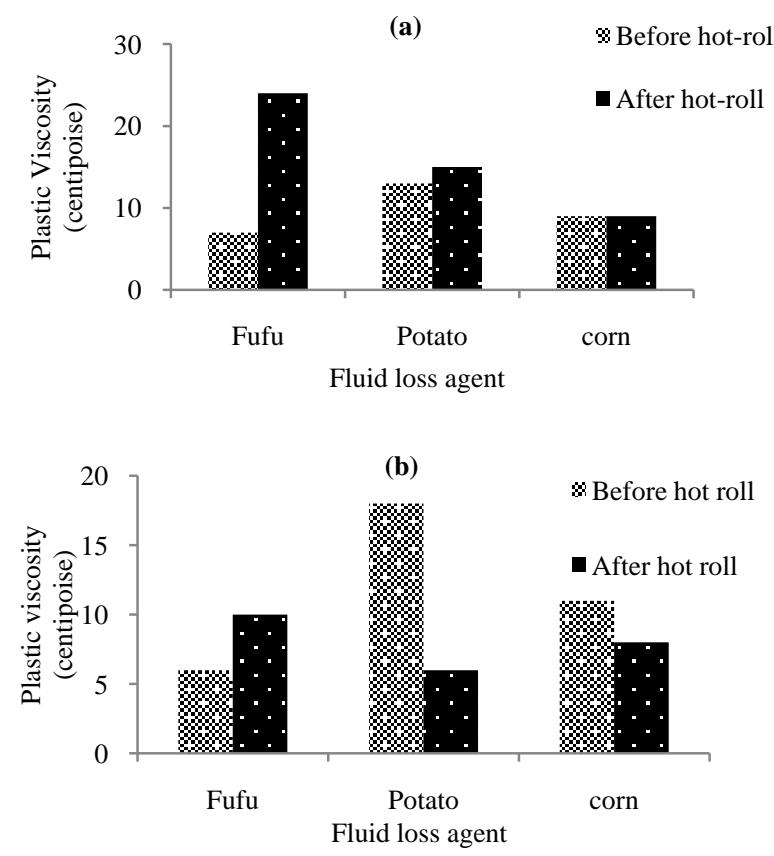

Fig. 2(a). The plastic viscosity before and after hot-roll in $250^{\circ} \mathrm{F}$ in mud weights of $100 \mathrm{pcf}(\mathrm{b})$ The plastic viscosity before and after hot-roll in $300^{\circ} \mathrm{F}$ in mud weights of 100 pcf.
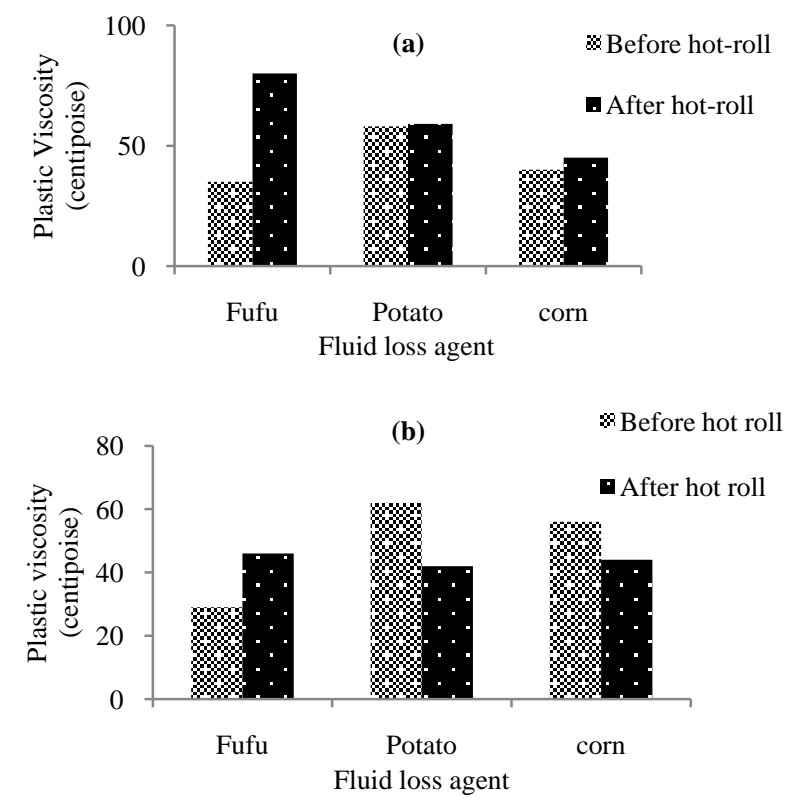

Fig. 3(a). The plastic viscosity before and after hot-roll in $250^{\circ} \mathrm{F}$ in mud weights of $150 \mathrm{pcf}(\mathrm{b})$ The plastic viscosity before and after hot-roll in $300^{\circ} \mathrm{F}$ in mud weights of $150 \mathrm{pcf}$. 


\section{The Effect of Hot-Roll Temperature on Apparent Viscosity}

Apparent Viscosity (AV) is the amount of shear stress that can be used for determining the changes of drilling mud when subjected to drilling operation. However, there's no information on the sources that contribute to the AV changes, unlike the plastic viscosity. Fig. 4(a) presents the AV of $f u f u$ after hot-roll in $250^{\circ} \mathrm{F}$ with light mud weight of $75 \mathrm{pcf}$ has raised significantly while potato and corn have remained about the same. An opposite reaction has occurred for $300^{\circ} \mathrm{F}$ as after hot rolling apparent viscosity of potato and corn starch been reduced while fufu had a slight increase (Fig. 4(b)).
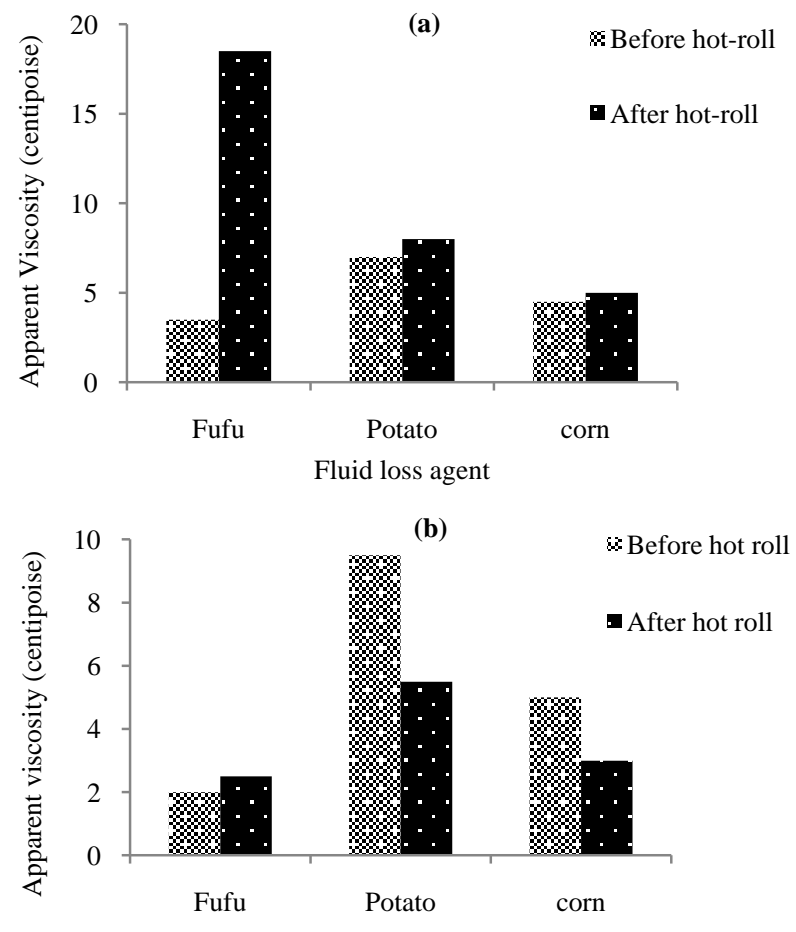

Fluid loss agent

Fig. 4(a). The apparent viscosity before and after hot-roll in $250^{\circ} \mathrm{F}$ in mud weights of 75 pcf (b) The apparent viscosity before and after hot-roll in $300^{\circ}$ $\mathrm{F}$ in mud weights of 75 pcf.
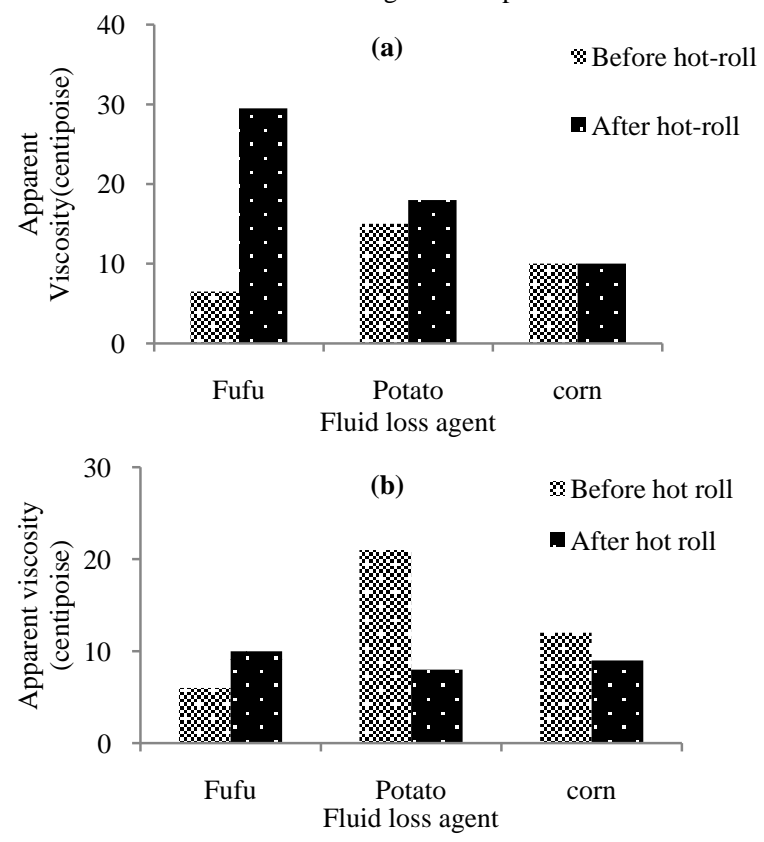

Fig. 5(a). The apparent viscosity before and after hot-roll in $250^{\circ} \mathrm{F}$ in mud weights of $100 \mathrm{pcf}(\mathrm{b})$ The apparent viscosity before and after hot-roll in $250 \mathrm{~F}$ in mud weights of $100 \mathrm{pcf}$.
AV of the fluid loss agents in average and heavy mud weights of 100 and $150 \mathrm{pcf}$, respectively, for temperatures of $250^{\circ} \mathrm{F}$ and $300^{\circ} \mathrm{F}$ are presented in Fig. 5 and Fig. 6. They showed about the same result as Fig. 4, with similar pattern in $\mathrm{AV}$ of light mud weight. For the quantitative evaluation of $\mathrm{AV}$, the heavier the mud this higher the AV changes (reduce/increase) recorded in both hot-roll temperatures.

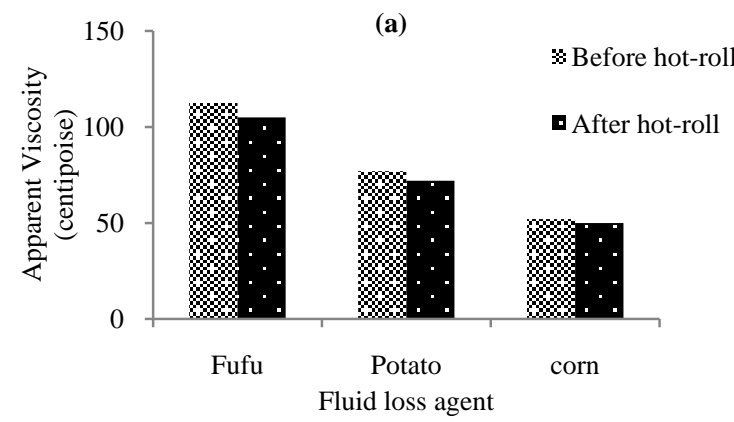

(b)

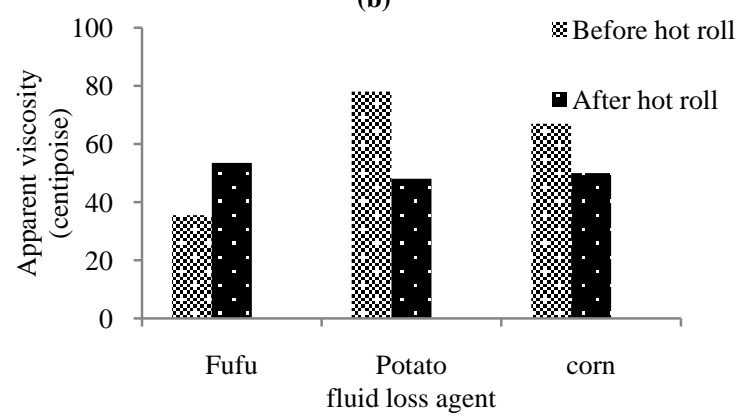

Fig. 6(a). The apparent viscosity before and after hot-roll in $250^{\circ} \mathrm{F}$ in mud weights of $150 \mathrm{pcf}(\mathrm{b})$ The apparent viscosity before and after hot-roll in $300^{\circ}$ $\mathrm{F}$ in mud weights of $150 \mathrm{pcf}$.
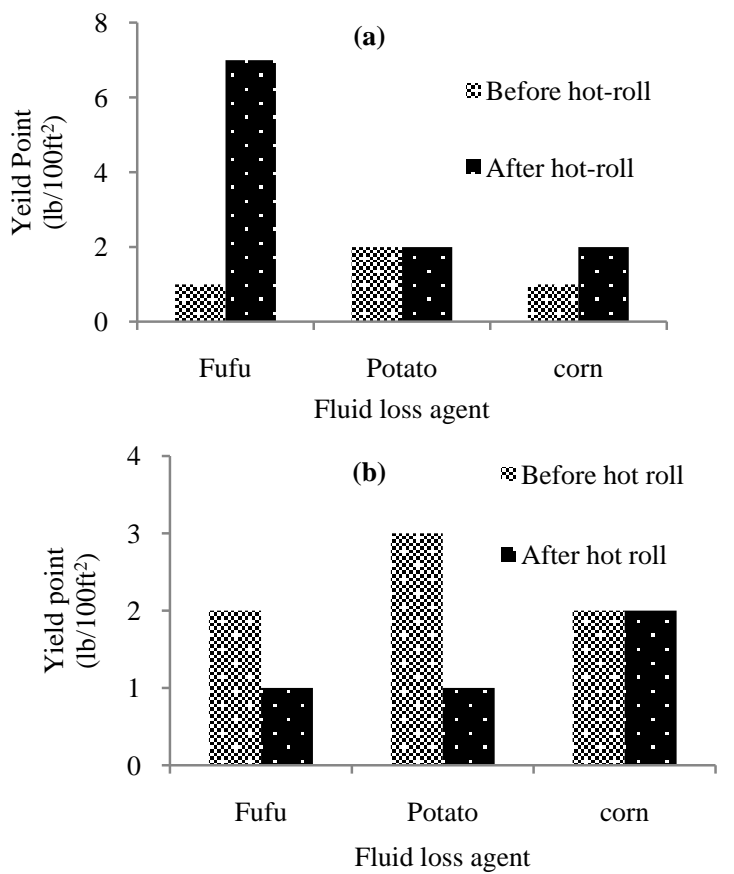

Fig. 7(a). The yield point before and after hot-roll in $250^{\circ} \mathrm{F}$ in mud weights of $75 \mathrm{pcf}$ (b) The yield point before and after hot-roll in $300^{\circ} \mathrm{F}$ in mud weights of $75 \mathrm{pcf}$.

\section{The Effect of Hot-Roll Temperature on Yield Point}

Yield point results from the present of an active solid material and effect of the inactive solid material density in the mud. Solids are divided into two groups; active and inert. 
Barite and hematite are among the inert or inactive solids used as drilling mud additives. Barite is a slightly active, and able to form weak chemical bonds. In contrast, hematite is made up of a type of iron oxide that lacks of active electron. Otherwise, it will have chemical activity and able to make stronger intermolecular bonds causing moving forces of intermolecular gravitation and yield point. This is a undesirable feature of mud. Since yield point and inter-molecular bonding are made by barite, the more the amount of barite added, the higher the YP would be.
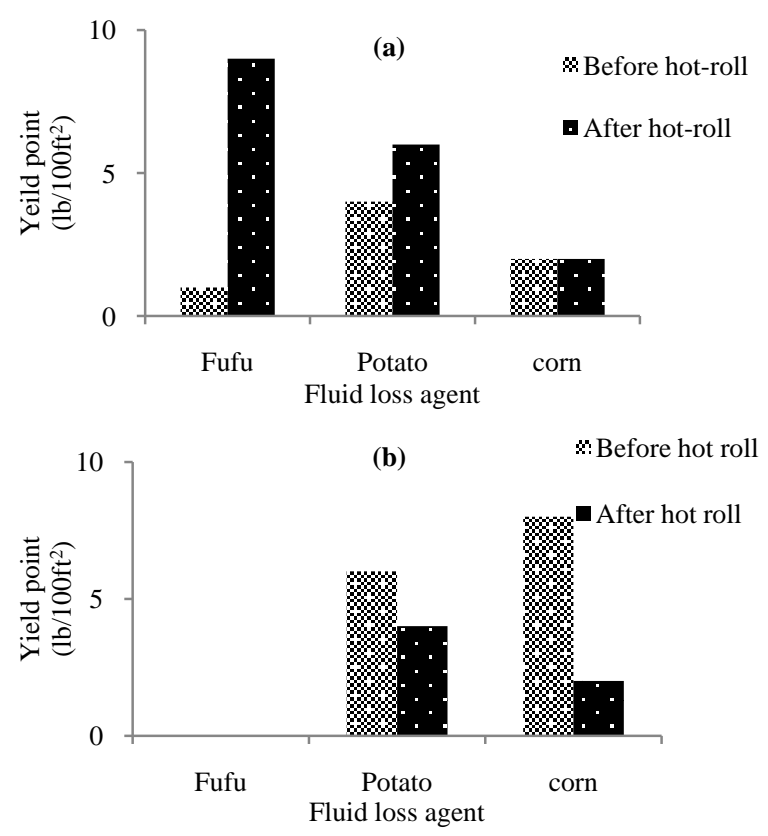

Fig. 8(a). The yield point before and after hot-roll in $250^{\circ} \mathrm{F}$ in mud weights of $100 \mathrm{pcf}$ (b) The yield point before and after hot-roll in $300^{\circ} \mathrm{F}$ in mud weights of $100 \mathrm{pcf}$.
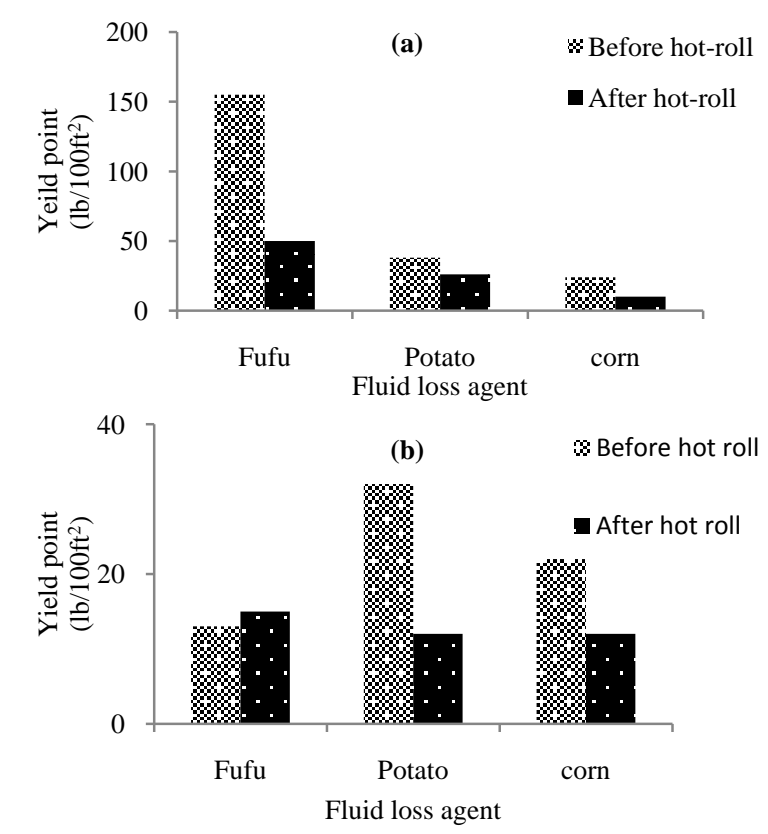

Fig. 9(a). The yield point before and after hot-roll in $250^{\circ} \mathrm{F}$ in mud weights of $150 \mathrm{pcf}$ (b) The yield point before and after hot-roll in $300^{\circ} \mathrm{F}$ in mud weights of $150 \mathrm{pcf}$.

Fig. 7(a) presents the YP of fufu after hot-roll in $250^{\circ} \mathrm{F}$ with light mud weight of $75 \mathrm{pcf}$ has raised significantly and recorded the highest yield point among there fluid loss agents.
Meanwhile, the YP of potato sample remained the same whereas corn sample showed a slight increment. An opposite observation has occurred for $300^{\circ} \mathrm{F}$ as the YP of fufu and potato diminished, while corn retained it $\mathrm{YP}$ as that before the hot-roll value (Fig. 7(b)).

Fig. 8(a) presents the YP of average mud weight (100 pcf) at temperature $250^{\circ} \mathrm{F}$ for the three fluid loss agent. The YP of $f u f u$ risen after the hot roll and recorded the highest YP value as compared to the other fluid loss agent. Potato starch showed a slight increment in the YP, while corn starch retained its value. In the temperature of $300^{\circ} \mathrm{F}$, fufu revealed a zero yield point, while corn and potato starch also had a decreasing in yield point after hot-rolling as shown in Fig. 8(b).

For heavy mud weight of $150 \mathrm{pcf}$ and temperature of $250^{\circ}$ F, YP of fufu dropped significantly, while potato and corn starch had a slight reduction, as presented in Fig. 9(a). In temperature of $300^{\circ} \mathrm{F}$, fufu had a slight increment in it's YP, while potato and corn starch had decreased to the same YP value (Fig. 9(b)).

\section{E. The Effect of Hot-Roll Temperature on Gel Strength}

The gel strength (GS) of a mud is a determination of the shearing stress required to initiate a limited rate of shear. By means of appropriate GS, suspended solids in the hole will settle out on the mud surface. The extreme GS can cause an inconsistent drilling tribulation. GS evaluation at time lag of 10 seconds and 10 minutes was investigated for all the mud samples. During this period, the mud is stable and all the available bonds between particles will be recovered [31]-[33].
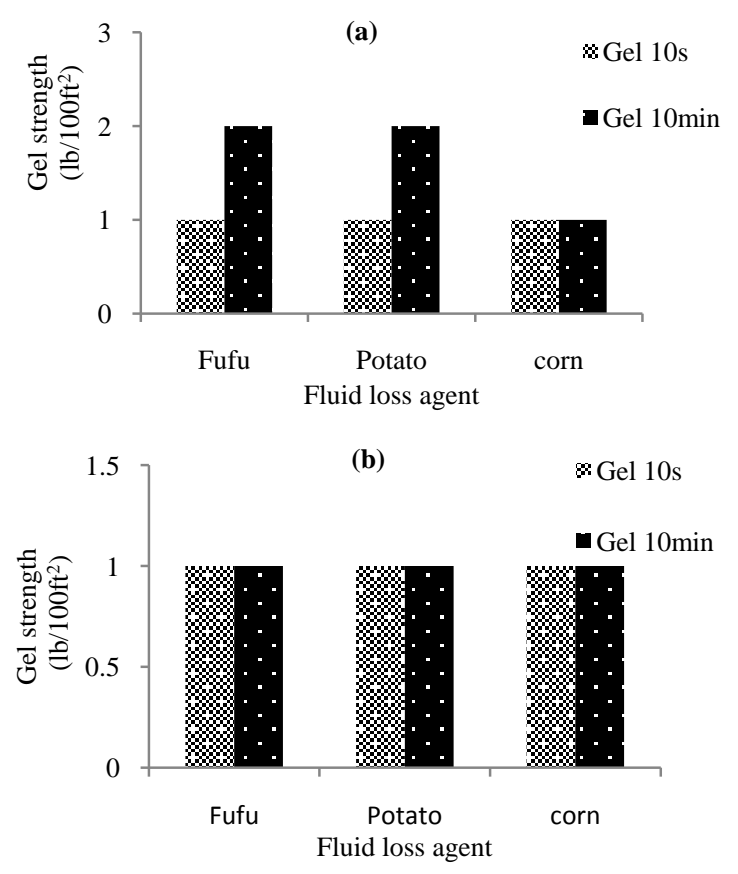

Fig. 10(a). The gel strength after hot-roll in $250^{\circ} \mathrm{F}$ in mud weights of $75 \mathrm{pcf}$ (b) The gel strength after hot-roll in $300 \mathrm{~F}$ in mud weights of 75 pcf.

Fig. 10(a) presents GS profile of light mud weight samples (75 pcf) in temperature of $250^{\circ} \mathrm{F}$ after hot-roll. The GS was measured at time lag 10 seconds and $10 \mathrm{~min}$. The GS of $f u f u$ showed an increment from 10 s to $10 \mathrm{~min}$, which is identical to that observed in potato sample. While corn GS remain unchanged from time lag of 10 seconds to 10 minutes. In the temperature of $300^{\circ} \mathrm{F}$ gel strength $(10$ seconds and 10 
minutes), all the fluid loss samples shown no changes (Fig. 10(b)).

Fig. 11(a) presents the GS of all the average mud weight samples (100 pcf) under temperature of $250^{\circ} \mathrm{F}$. The GS (10 minutes) increased in both fufu and potato starch while corns starch remained constant. At temperature of $300^{\circ} \mathrm{F}$, fufu and corn remained constant while potato's GS raised significantly (Fig. 11(b)). By comparing the effect of temperature, potato and corn showed no changes in their GS value. On the other hand, the GS value of fufu is temperature affected.
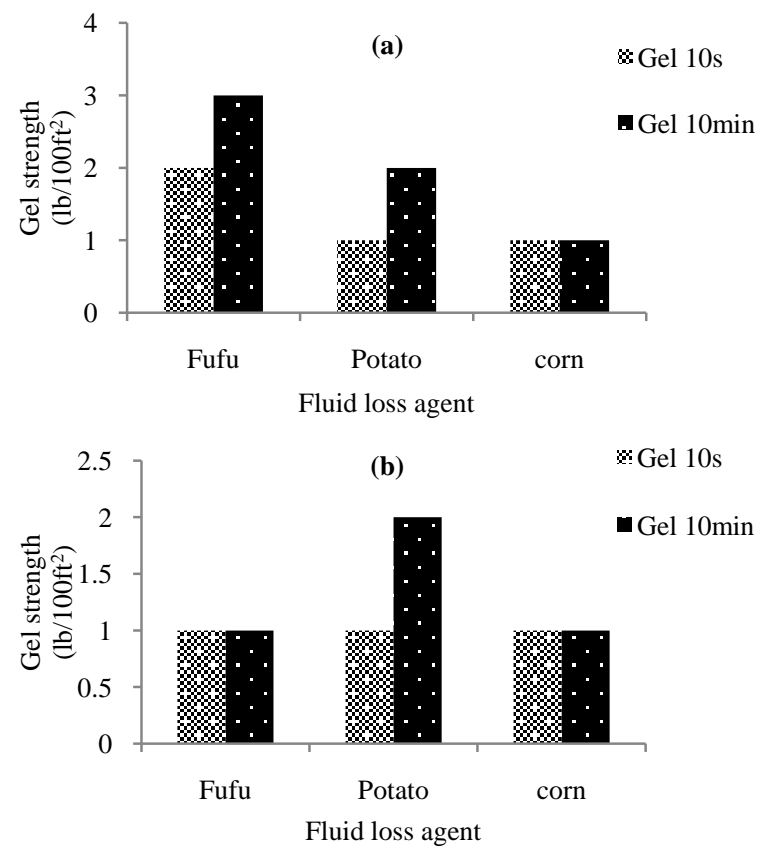

Fig. 11(a). The gel strength after hot-roll in $250^{\circ} \mathrm{F}$ in mud weights of $100 \mathrm{pcf}$ (b) The gel strength after hot-roll in $300 \mathrm{~F}$ in mud weights of $100 \mathrm{pcf}$.

Fig. 12 presents GS of all samples in temperature of $250^{\circ} \mathrm{F}$ and $300^{\circ} \mathrm{F}$ for heavy mud weight of 150 pcf. In all samples, the GS (10 minutes) increased slightly. The GS in these heavy muds in both temperatures was very high compared to the other light and average mud weights formulation.
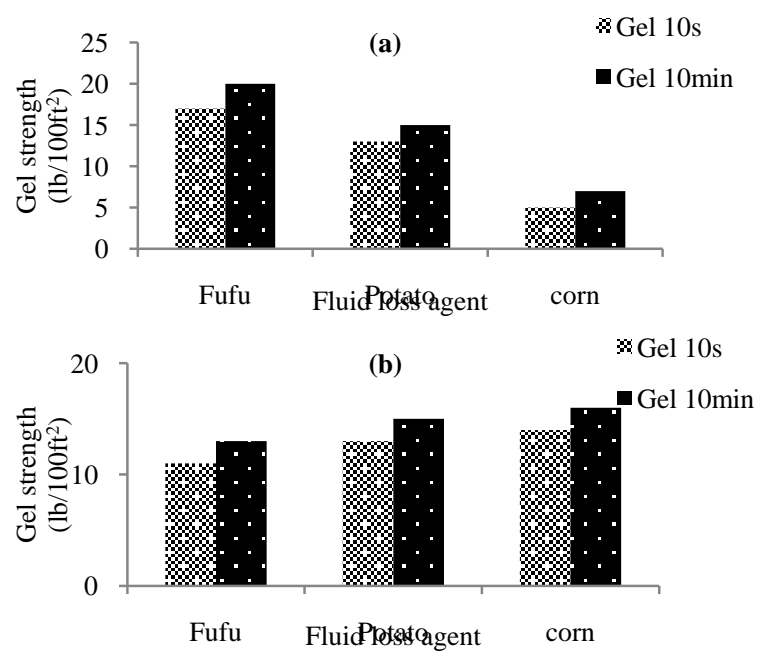

Fig. 12(a). The gel strength after hot-roll in $250^{\circ} \mathrm{F}$ in mud weights of $150 \mathrm{pcf}$ (b) The gel strength after hot-roll in $300 \mathrm{~F}$ in mud weights of $150 \mathrm{pcf}$.

\section{F. The Effect of Hot-Roll Temperature on $\mathrm{pH}$}

The results presented in Fig. 13, Fig. 14 and Fig. 15 revealed that all the fluid loss agent samples in different mud weights were around neutral $\mathrm{pH}$ values ( $\mathrm{pH}$ around 7) before hot-roll. The light formulation of $f u f u$, potato and corn based mud showed mild acidic after hot rolling at $250^{\circ} \mathrm{F}$. Meanwhile, at $300^{\circ} \mathrm{F}$ hot roll treatment, all the muds (except in the 75 pcf formulation) were in neutral-mild alkaline state ( $\mathrm{pH}$ more than 7-8).
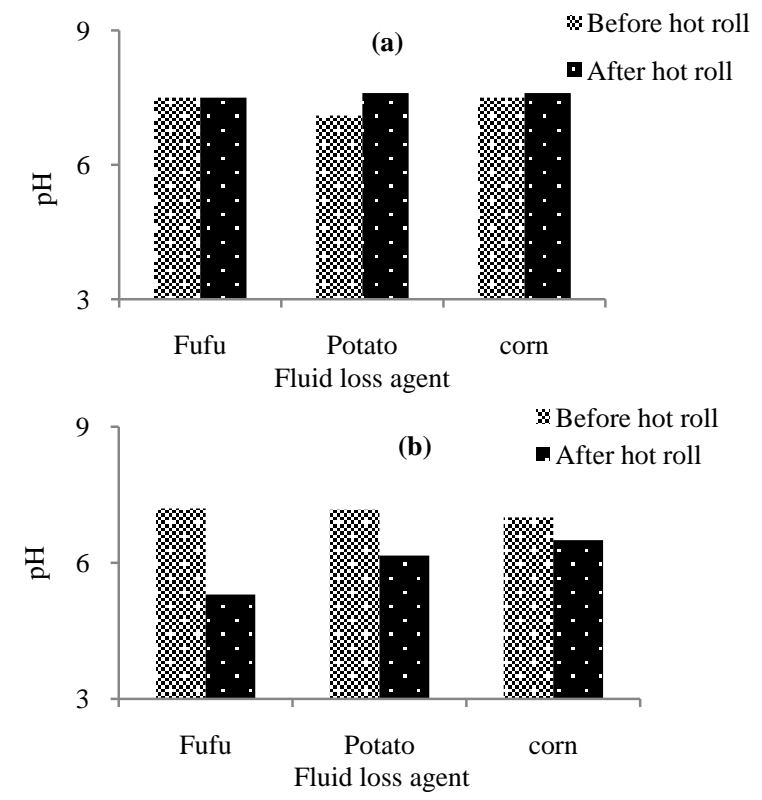

Fig. 13(a). The pH evaluation before and after hot-roll in $250^{\circ} \mathrm{F}$ in mud weights of $75 \mathrm{pcf}$ (b) The $\mathrm{pH}$ evaluation before and after hot-roll in $300^{\circ} \mathrm{F}$ in mud weights of $75 \mathrm{pcf}$.
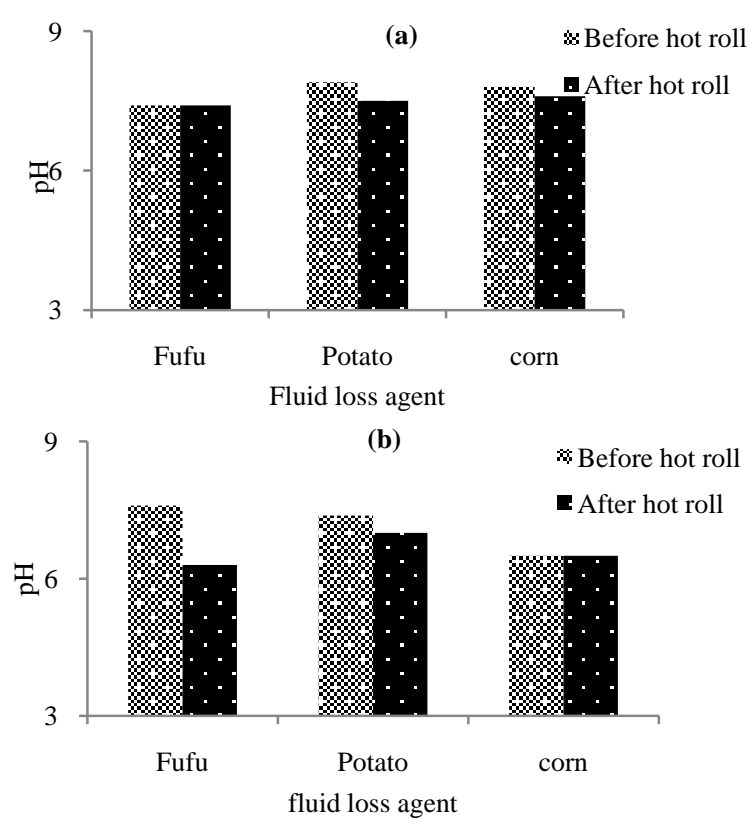

Fig. 14(a). The pH evaluation before and after hot-roll in $250^{\circ} \mathrm{F}$ in mud weights of $100 \mathrm{pcf}$ (b)The $\mathrm{pH}$ evaluation before and after hot-roll in $300^{\circ} \mathrm{F}$ in mud weights of $100 \mathrm{pcf}$.

\section{G. The Effect of Hot-Roll Temperature on Fluid Loss}

Investigation on the fluid loss properties were carried out using an API proved high pressure-high temperature filter press (HPHT) manufactured by Fann (model 3878, USA). As NISOC standard requires acceptable amount of fluid loss for water based drilling muds is up to $2 \mathrm{ml}$. Value of higher than $2 \mathrm{ml}$ is considered rejected as a fluid loss agent. As shown in 
Fig. 16(a), Fig. 17(a) and Fig. 18(a), at the temperature of $250^{\circ} \mathrm{F}$, fufu has an acceptable fluid loss (less than 2 ) in all the mud weights. Potato and corn in the light-weight muds were rejected because the fluid loss values are above 2 .
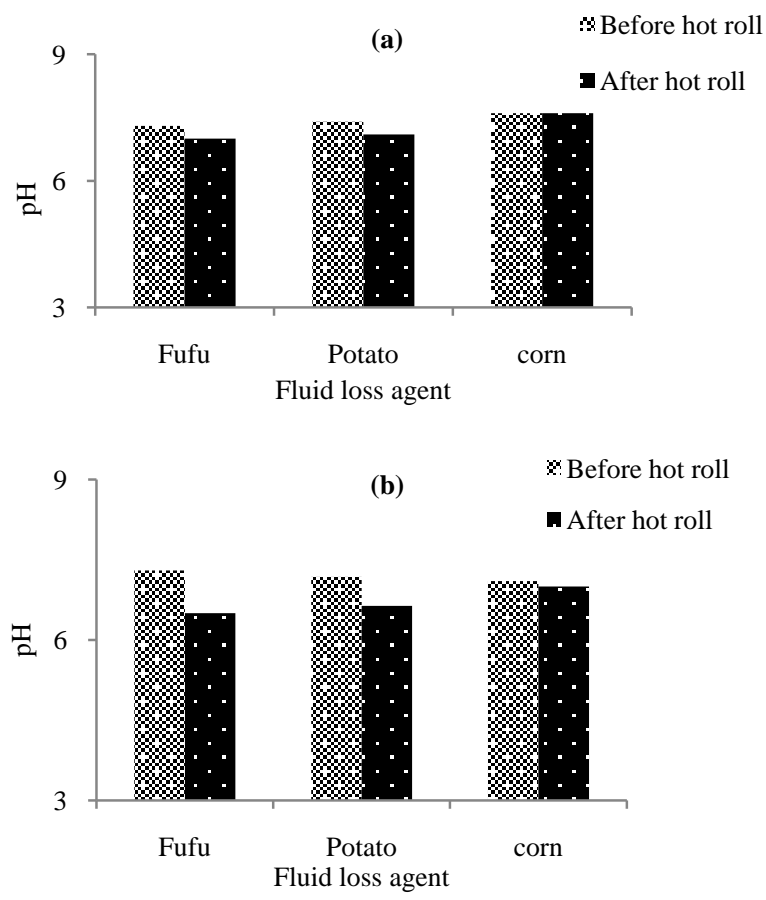

Fig. 15(a). The $\mathrm{pH}$ evaluation before and after hot-roll in $250^{\circ} \mathrm{F}$ in mud weights of $150 \mathrm{pcf}$ (b) The $\mathrm{pH}$ evaluation before and after hot-roll in $300^{\circ} \mathrm{F}$ in mud weights of $150 \mathrm{pcf}$.
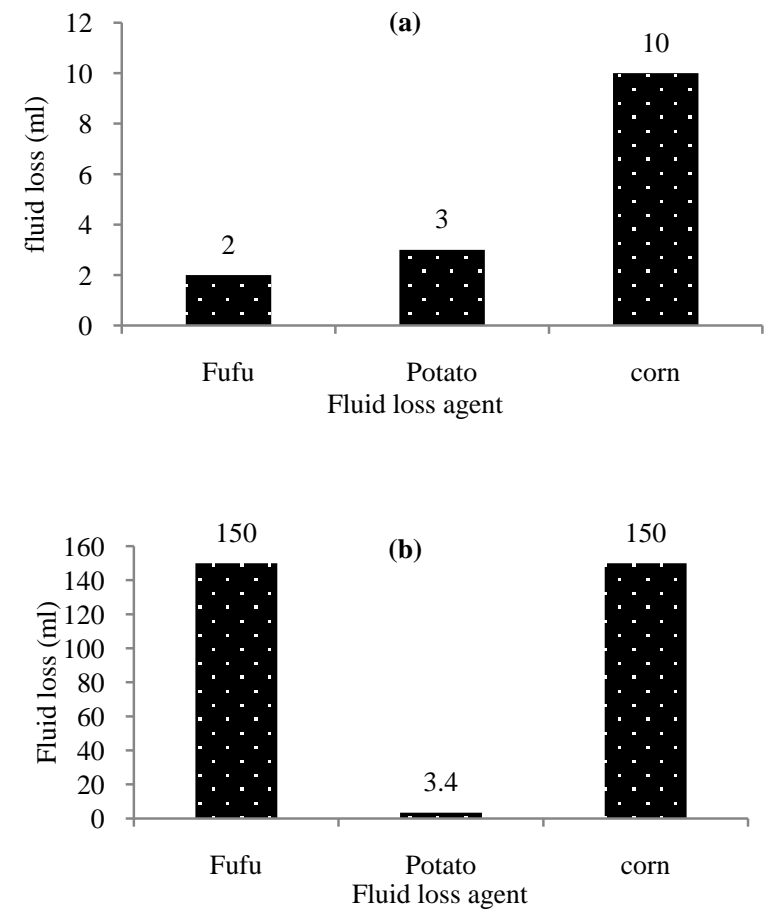

Fig. 16(a). The fluid loss evaluation after hot-roll in $250^{\circ} \mathrm{F}$ in mud weights of $75 \mathrm{pcf}$ (b) The fluid loss evaluation after hot-roll in $300^{\circ} \mathrm{F}$ in mud weights of 75 pcf.

At the temperature of $300^{\circ} \mathrm{F}$ as shown in Fig. 16(b), Fig. 17(b), all the samples of fluid loss agents exceeded the acceptable fluid loss range and were rejected (more than 2 $\mathrm{ml}$ ). The only acceptable fluid loss agent was potato (in 150 pcf) with fluid loss of $1.6 \mathrm{ml}$ (Fig. 18(b)).
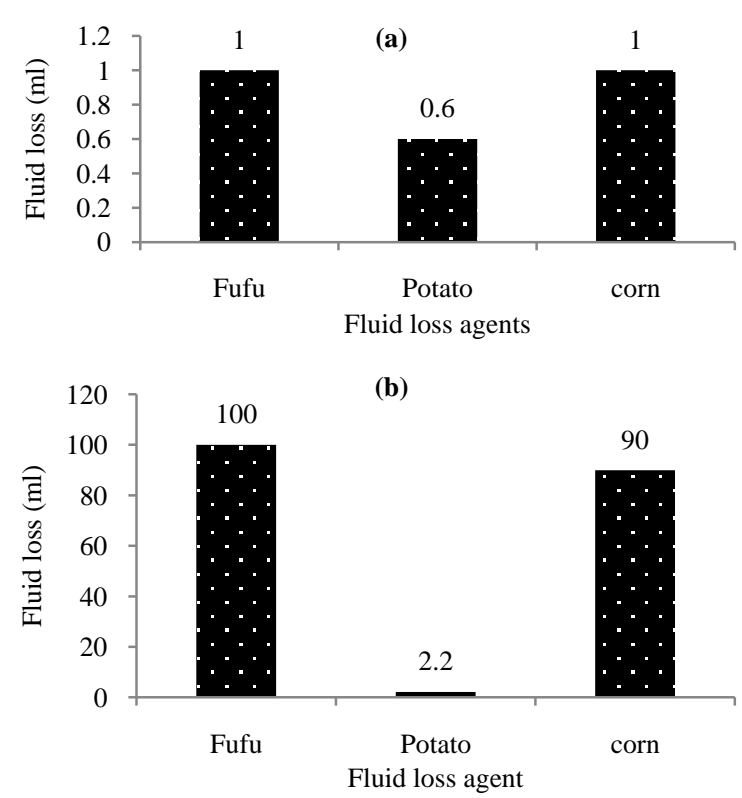

Fig. 17(a). The fluid loss evaluation after hot-roll in $250^{\circ} \mathrm{F}$ in mud weights of $100 \mathrm{pcf}(\mathrm{b})$ The fluid loss evaluation after hot-roll in $300^{\circ} \mathrm{F}$ in mud weights of $100 \mathrm{pcf}$.
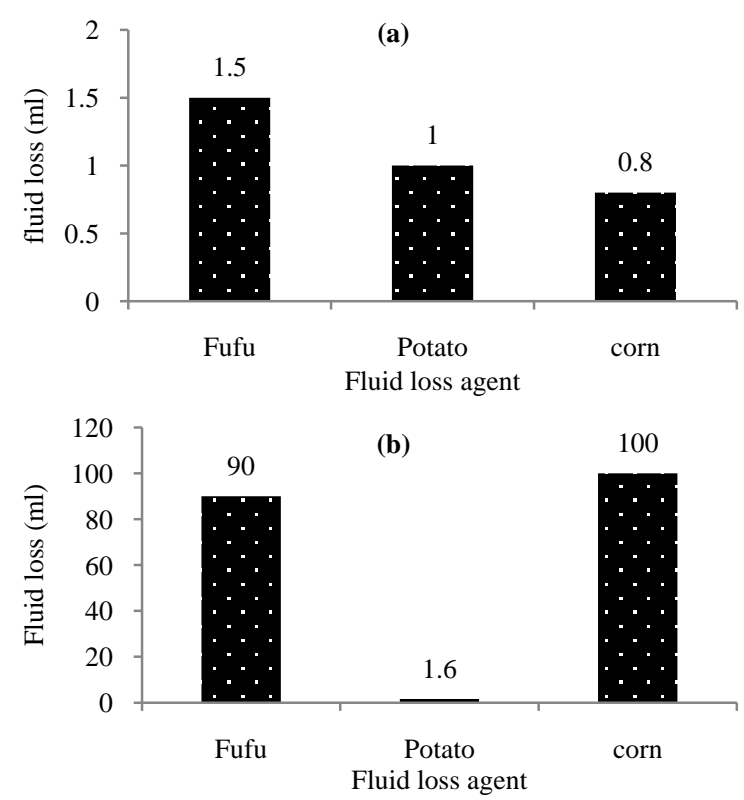

Fig. 18(a). The fluid loss evaluation after hot-roll in $250^{\circ} \mathrm{F}$ in mud weights of $150 \mathrm{pcf}(\mathrm{b})$ The fluid loss evaluation after hot-roll in $300^{\circ} \mathrm{F}$ in mud weights of $150 \mathrm{pcf}$.

\section{CONCLUSION}

This work showed the potential of $f u f u$ a cassava derivative as a fluid loss control additive in water based drilling muds. An acceptable and compatible amount of fluid loss was reported in all the mud weights applied $(75,100$ and 150pcf) within the temperature of $250^{\circ} \mathrm{F}$. Potato and corn-starch failed the fluid loss requirement in light mud weight of $75 \mathrm{pcf}$. Even though $f u f u$ failed as a fluid loss control additive in extreme temperature of $300^{\circ} \mathrm{F}$ in all the applied mud weights, the same failure was also observed in potato and corn samples.

\section{ACKNOWLEDGMENT}

The authors expressing their gratitude to PARS Drilling 
Fluid Company, Tehran/Iran for provision of Drilling mud laboratory and facilities in this investigation and Mr. Mojtaba Kalhor for his technical supervision and advisory for Ms. Raheleh Samavati.

\section{REFERENCES}

[1] J. J. Rayborn and J. P. Dickerson, "Method of making a drilling fluid containing carbon black in a dispersed state," U.S. Patent 5114597 , 1992.

[2] P. J. Cranford, D. C. Gordon, K. Lee, S. L. Armsworthy, and G. H. Tremblay, "Chronic toxicity and physical disturbance effects of waterand oil-based drilling fluids and some major constituents on adult sea scallops (Placopecten magellanicus)," Marine Environmental Research, vol. 48, no. 3, pp. 225-256, 1999.

[3] M. F. Strachan and P. F. Kingston, "A comparative study on the effects of barite, limonite and bentonite on for suspension feeding bivalves," Marine Pollution Bulletin, vol. 64. pp. 2029-2038, 2012.

[4] Drilling Engineering Handbook, New York: Springer- Netherlands, 1983, pp. 32-57.

[5] W. Bergthaller and J. Hollmann, Starch, in Comprehensive Glycoscience, Elsevier: Oxford. 2007, pp. 579-612.

[6] J. Thomas, K. Shah, J. Kasica and I. Shah, "Thermally inhibited polysaccharides and process of preparing," U. S. Patent 9640793, 2012.

[7] K. A. Abbas, S. Khalil, and A. S. Meor Hussin. (2010). Modified Starches and Their Usages in Selected Food Products: A Review Study. $\begin{array}{llll}\text { Agricultural } & \text { Sience. } & \text { [Online]. 2(2). Availible: }\end{array}$ http://www.ccsenet.org/journal/index.php/jas/article/view/4069.

[8] T. Hamida, E. Kuru, and M. Pickard, "Filtration loss characteristics of aqueous waxy hull-less barley (WHB) solutions," Petroleum Science and Engineering, vol. 72, issue 1-2. pp. 33-41, 2010.

[9] G. R. Gray, H. C. H. Darley, and W. F. Rogers, Composition and Properties of Oil Well Drilling Fluids, Gulf Publishing, 1980.

[10] R. Caenn, H. C. H. Darley, and G. R. Gray, Composition and Properties of Drilling and Completion Fluids, $6^{\text {th }}$ ed, Gulf Professional Publishing, 2011.

[11] American Institute of Petroleum, Petroleum Review, Institute of Petroleum, vol 52, 1998.

[12] W. C. Chin, Formation Invasion: With Applications to Measurement-While-Drilling, Time Lapse Analysis, and Formation Damage, Gulf Publishing, 1995.

[13] C. P. Anderson, Drilling mud fluid loss an alternative expensive bulk polymers, 1991.

[14] I. Issham and I. A. Kamal, "The prospect of utilizing local starches and fluid loss control agents in the petroleum industry," in Proc. Regional Symposium on Chemical Engineering Conf., Johor, Malaysia, 1997, pp. 375-386.

[15] T. E. Hudson and M. D. Coffey, "Fluid loss control through the use of a liquid thickened completion and work over brine," Journal of Petroleum Technology, vol. 35, no. 10, pp. 1776-1782, 1983.

[16] F. Engelhardt, "Sulfur Containing Di-tert-butylphenol Compounds Use full as Anti-inflammatory Agents," U.S. Patent 551036 A, 1996.

[17] M. D. Amanullah and Y. Long, "Superior corn-based starches for oil field application, in New Director for a Diverse Planet," presented at the 4th International Conference on Corns., Brisbane, Australia, 2004.

[18] I. Okumo and S. O. Isehunwa, "Prediction of the Viscosity of a Potash at Varying Temperatures Using Factorial Design," presented at the Nigeria Annual International Conference and Exhibition, Abuja, Nigeria. 2007.

[19] O. J. Ikegwu, V. N. Nwobasi, M. O. Odoh, and N. Z. Oledinma. "Evaluation of the pasting and some functional properties of starch isolated from some improved cassava varieties in Nigeria," African Journal of Biotechnology, vol. 8, no. 10, pp. 2310-2315, 2009.

[20] T. Ademiluyi, O. F. Joel, and A. K. Amuda, "Investigation of local Polymer (Cassava Straches) as a Substitute for Imported Sample in
Viscosity and Fluid Loss Control of Water Based drilling Mud," ARPN Journal of Engineering and Applied Sciences. vol. 6, no. 12, 2001.

[21] P. W. Fischer, J. P. Gallus, and P. Brea, Method for drilling a well through Unconsolidated Dolomite Formation," U.S. Patent 4120369 1978.

[22] R. Caenn and G. V. Chillingar, "Drilling fluids: State of the art," Journal of Petroleum Science and Engineering, vol. 14, issue 3-4. pp. 221-230, 1996.

[23] China national petroleum corporation. (2008). CNCP Succesfully Completed Drilling on Deepest Onshore Well in China. [Online]. Available: http://www.Rigzone.com/news/article.as

[24] Oil Industry Network of Iran. (2011). Drilling an Oil Well. [Online]. Available: http://naft.info/content_management.

[25] M. A. Ayankunbi, O. O. Keshinro, and P. Egele, "Effect of methods of preparation on the nutrient composition of some cassava products-Garri (eba), 'Lafun' and 'Fufu',' Food Chemistry, vol. 41, issue 3, pp. 349-354, 1991

[26] A. O. Ketiku and V. A. Oyenuga, "Preliminary report on the carbohydrate constituents of cassava root and yam tuber," Nigerian Journal of Science. vol. 4, pp. 25-29, 1970.

[27] R. Howeler, "Cassava in Asia: Trends in cassava production, processing and marketing," in Partnership in Modern Science to Develop a Strong Cassava Commercial Sector in Africa and Appropriate Varieties by 20202006, CIAT Cassava Office for Asia, Department of Agriculture: Bellagio, Italy.

[28] A. O. Ogunsua, "Changes in some chemical constituents during the fermentation of cassava tubers (Manihot esculenta,Crantz)," Food Chemistry, vol. 5, issue 3, pp. 249-255, 1980.

[29] V. A. Oyenuga, Nigeria's Foods and Feeding-stuffs, $3^{\text {rd }}$ Ed, Ibadan University Press, 1968.

[30] O. B. Oyewole and S. A. Odunfa, "Effects of fermentation on the carbohydrate, mineral, and protein contents of cassava during "fufu" production," Journal of Food Composition and Analysis, vol. 2, issue 2, pp. 170-176, 1989.

[31] G. V. Chilingar and P. Vorabutr, Drilling and Drilling Fluids, Elsevier Publishing. 1983.

[32] I. S. Dairanieh and S. M. Lahalih, "Novel polymeric drilling mud viscosifiers," European Polymer Journal, vol. 24, issue 9, pp. 831-835, 1988.

[33] P. E. Clark, "Drilling Mud Rheology and the API Recommended Measurements," presented at the in SPE Production Operations Symposium conference, Oklahoma City, Oklahoma. 1995.

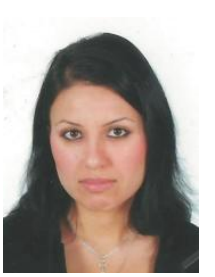

Raheleh Samavati is a Ph.D. studentat the Department of Chemical and Environmental Engineering (Material and Science Engineering), Universiti Putra Malaysia. Her research activities are in the area of starch based drilling fluids. She can be contacted at e-mail: samavati_raheleh@yahoo.com.

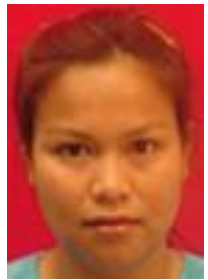

Norhafizah Abdullah is a lecturer at the Department of Chemical and Environmental Engineering, Universiti Putra Malaysia and the head of Material Characterization Laboratory at Faculty of Engineering, Universiti Putra Malaysia. Her research activities are in the area of purification engineering and macromolecules design for drug delivery and formulation. She can be contacted at e-mail: nhafizah@upm.edu.my. 